\title{
Immobilization of Lycinibacillus fusiformis B26 cells in different matrices for use in turquoise blue HFG decolourization
}

\author{
Nazime Mercan Dogan ${ }^{1}$, Tugba Sensoy ${ }^{1}$, Gulumser Acar Doganli", Naime Nur Bozbeyoglu ${ }^{1}$, \\ Dicle Arar ${ }^{1}$, Hatice Ardag Akdogan ${ }^{3}$, Merve Canpolat ${ }^{3}$ \\ ${ }^{1}$ Pamukkale University, Turkey \\ Faculty of Science and Arts, Department of Biology \\ ${ }^{2}$ Pamukkale University, Turkey \\ Faculty of Technology, Department of Biomedical Engineering \\ ${ }^{3}$ Pamukkale University, Turkey \\ Faculty of Science and Arts, Department of Chemistry \\ *Corresponding author's e-mail: gulumseracar@pau.edu.tr
}

Keywords: agar, calcium alginate, decolourization, FTIR, immobilization, pumice.

\begin{abstract}
The decolourization of Turquoise Blue HFG by immobilized cells of Lysinibacillus fusiformis B26 was investigated. Cells of $L$. fusiformis B26 were immobilized by entrapment in agar and calcium alginate matrices and attached in pumice particles. The effects of operational conditions (e.g., agar concentrations, cell concentrations, temperature, and inoculum amount) on microbial decolourization by immobilized cells were investigated. The results revealed that alginate was proven to be the best as exhibiting maximum decolourization (69.62\%), followed by agar $(55.55 \%)$ at $40^{\circ} \mathrm{C}$. Pumice particles were the poorest. Optimum conditions for agar matrix were found: concentration was $3 \%$, cell amount was $0.5 \mathrm{~g}$ and temperature was $40^{\circ} \mathrm{C}(55.55 \%)$. Ca-alginate beads were loaded with $0.5,1.0$ and $2.0 \mathrm{~g}$ of wet cell pellets and the highest colour removal activity was observed with $2.0 \mathrm{~g}$ of cell pellet at $40^{\circ} \mathrm{C}$ for alginate beads. Also, 0.5 and $1.0 \mathrm{~g}$ of pumice particles that were loaded with 0.25 and $0.5 \mathrm{~g}$ of cell pellets respectively were used and the results were found very similar to each other.
\end{abstract}

\section{Introduction}

Synthetic dyes are extensively used in textile dyeing and many other industries (food, pharmaceutical, cosmetic, printing and leather industries) because of their ease and cost-effectiveness in synthesis, firmness, high stability to light, temperature, detergent and microbial attack and variety in color compared with natural dyes (Couto 2009). This has resulted in uncontrolled discharge of wastewater that contains polluted effluents of these industries. This leads to serious environmental problems. For example, colored effluents affect water transparency and gas solubility in water bodies and damage the aquatic systems (Banat et al. 1996). Such effluents lead to a reduction in sunlight penetration, which in turn decreases photosynthetic activity, dissolved oxygen concentration, and water quality, and has acute toxic effects on aquatic flora and fauna, causing severe environmental problems worldwide (Vandevivere et al. 1998, Zou et al. 2015). In addition, many dyes are believed to be toxic carcinogens or to be prepared from known carcinogens such as benzidine or other aromatic compounds that might be formed as a result of microbial metabolism (Novonty et al. 2006, Kariminiaae-Hamedaani et al. 2007). Therefore, removal of such dyes before discharging them into natural water streams is essential. For this, appropriate treatment technologies are required. The treatment of recalcitrant and toxic dyes with traditional technologies is not always effective or may not be environmentally friendly. Also, these methods are generally expensive, have limited applicability and produce large amounts of sludge. However, the biological remediation of textile effluents has recently received an increasing attention, representing an attractive, cheap, environmentally friendly, and publicly acceptable alternative (Banat et al. 1996) to the physico-chemical methods (Yang et al. 2003). Within this context, a wide variety of microorganisms such as bacteria, actinomycetes, algae and fungi found in soil and water are able to decolorize synthetic dyes (Mohana et al. 2008, Chacko and Subramaniam 2011, Khalid et al. 2012). These microorganisms can be used as either free or immobilized cells for color removal. Immobilized cells and enzymes have been attracting great attention since the 1970s (Couto 2009). Using immobilized cells have several advantages over free cells. For example, easier liquid-solid separation, enhanced yield, reduced risk of contamination, better operational stability and cell viability for several cycles of operations (Nigam 2000, Chandel et al. 2007). In addition, immobilized 
cultures tend to have a higher level of activity and are more resilient to environmental perturbations such as $\mathrm{pH}$, or exposure to toxic chemical concentrations than suspension cultures (Shin et al. 2002) and immobilization protects the cells from shear damage (Abraham et al. 1991, Fiedurek and Ilczuk 1991, Vassilev and Vassileva 1992).

There are two basic cell immobilization methods: entrapment and attachment. Entrapment of microbial cells within the polymeric matrices such as calcium alginate, agar agar, k-carrageenan, gelatin, etc. have been studied widely (Adinarayana et al. 2005, Kar et al. 2009). Two most suitable carriers for cell immobilization are entrapment in agar agar cubes (Kar et al. 2009) and calcium alginate bead (Kar and Ray 2008) because these techniques are simple, cost effective and nontoxic. On the other hand, a large variety of carriers (or supports) are used for cell immobilization. The micro-organisms adhere or attach to surfaces (e.g. pumice, sponge, and ceramic) by self-adhesion or chemical bonding.

The present study was carried out to determine the decolourization potential of Lysinibacillus fusiformis B26 cells immobilized in two most suitable matrices (agar agar and calcium alginate) and one carrier (pumice) with different cell concentration and temperature.

\section{Material and methods}

\section{Dye stock}

The industrial quality Turquoise Blue HFG dye stock solution was obtained from Dystar Textile Co., Turkey (Fig. 1). The powdered dyestuff was dissolved in distilled water at 1000 $\mathrm{mg} / \mathrm{L}(\mathrm{w} / \mathrm{v})$ and sterilized by filter for the preparation of dye stock. Appropriate volumes of the stock dye were added to growth medium containing flasks.

\section{Bacterial strain and growth}

The bacterial strain (L. fusiformis B26) used in the present work was obtained from the culture collection of the Pamukkale University, Bacteriology Laboratory (Turkey). The strain B26 was inoculated to a $1 \mathrm{~L}$ erlenmeyer flask containing $500 \mathrm{ml}$ Tryptic Soy Broth (TSB; g/L: Pepton from casein 17 , pepton from soy meal $3, \mathrm{D}(+)$ glucose 2.5 , sodium chloride 5 , dipotassium hydrogen phosphate 2.5$)$ medium and the culture was aerobically incubated with constant shaking at $125 \mathrm{rpm}, 40^{\circ} \mathrm{C}$ for $24 \mathrm{~h}$. Growing cells were harvested by centrifugation (6000 rpm/min, $20 \mathrm{~min}$ ) and washed twice with sterilized physiological water. Wet cell pellet was used for immobilization procedures.

\section{Immobilization in agar}

Desired amount of agar powder was dissolved in $0.9 \%$ $\mathrm{NaCl}$ solution (at the concentrations of $3 \%, 4 \%, 5 \%$ and $6 \%$ ) and sterilized by autoclaving at $121^{\circ} \mathrm{C}$ for $15 \mathrm{~min}$. The cell suspension (equivalent to $1 \%$ and $2 \%$ ) was added to the molten agar maintained at $30^{\circ} \mathrm{C}$, shaken well for a few seconds (without forming foam), poured into sterile petri-plates $(10 \times$ $100 \mathrm{~mm}$ diameter) and allowed to solidify. The solidified agar block was cut into equal size cubes and added to sterile $0.1 \mathrm{M}$ phosphate buffer ( $\mathrm{pH} 5.5)$, and kept in the refrigerator $(1 \mathrm{~h})$ for curing (Abdel-Naby et al. 2011). After curing, phosphate buffer was decanted and the cubes were washed with sterile distilled water three to four times and stored in sterile distilled water at $4^{\circ} \mathrm{C}$ until use.

\section{Immobilization in Ca-alginate}

$0.5 \mathrm{~g}, 1.0 \mathrm{~g}$ and $2.0 \mathrm{~g}$ cell pellets were mixed with $6 \mathrm{ml}$ of $2 \%(\mathrm{w} / \mathrm{v})$ sodium alginate solution prepared in distilled water. In order to obtain the beads, the slurry was extruded through a syringe into calcium chloride solution $(2 \% \mathrm{w} / \mathrm{v})$ and kept at $4{ }^{\circ} \mathrm{C}$ for $4 \mathrm{~h}$. After that, beads were washed with sterile physiological water (Puvaneswari et al. 2002) and used for inoculation of $50 \mathrm{ml}$ of the decolourization medium.

\section{Immobilization in pumice}

$0.5 \mathrm{~g}$ and $1.0 \mathrm{~g}$ pumice particles (at $1.40 \mathrm{~mm}$ diameter) were treated with $10 \mathrm{ml}$ of $0.1 \%$ glutaraldehyde overnight. Then, they were collected by centrifugation and washed with sterile physiological saline solution to remove the excess glutaraldehyde. Then the carrier ( $0.5 \mathrm{~g}$ and $1.0 \mathrm{~g}$ pumice) was combined in $10 \mathrm{ml}$ sterile physiologic saline with $0.25 \mathrm{~g}$ and $0.5 \mathrm{~g}$ cell pellets respectively and stored at $4^{\circ} \mathrm{C}$ overnight. Then the carriers were collected by centrifugation and washed with sterile water. The immobilized cells on 0.5 and $1.0 \mathrm{~g}$ pumice were used for inoculation of $50 \mathrm{ml}$ of the decolourization medium (Behera et al. 2010).

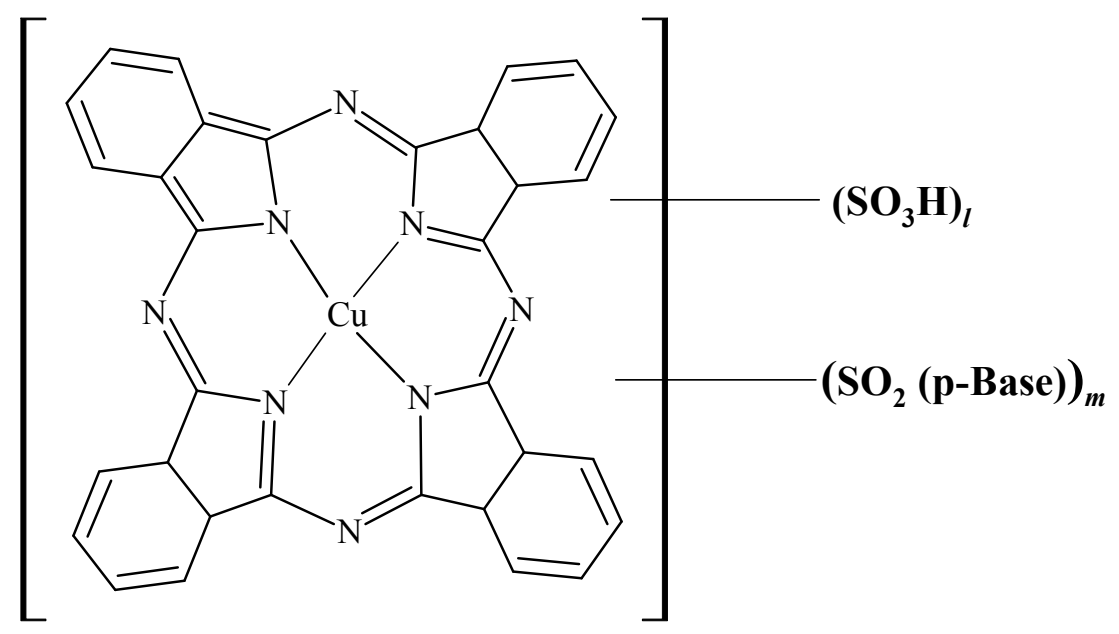

Fig. 1. Chemical structure of Turquise Blue HFG $(\lambda \max =595 \mathrm{~nm})$ 


\section{Decolourization of Turquoise Blue HFG by immobilized cells}

Microbial colour removal experiments were performed using immobilized cells of L. fusiformis B26 in $50 \mathrm{ml} \mathrm{LB}-$ Miller medium (g/L: Triptone 10 , yeast extract $5, \mathrm{NaCl} 10$ ) containing $50 \mathrm{mg} / \mathrm{L}$ Turquoise Blue HFG dye at $\mathrm{pH}$ 7.0. The experiments were performed at 40 and $50^{\circ} \mathrm{C}$ with constant shaking at $125 \mathrm{rpm}$. Immediately after inoculation with immobilized cells, samples were drawn at different time intervals and centrifuged at $14000 \mathrm{rpm}$ for $20 \mathrm{~min}$. The decolourization rate was monitored spectrophotometrically (UV-Vis Lange DR5000) by seeking the decrease in absorbance $(595 \mathrm{~nm})$ of the dye in culture supernatant. Decolorizing activity is expressed in terms of percentage decolourization and the decolourization efficiency was calculated using the following equation:

\section{Decolorization efficiency $(\%)=100 x(O D i-O D t) / O D i$}

Where ODi refers to the initial absorbance at $595 \mathrm{~nm}$ and ODt refers to the absorbance measured in the degradation. The percentage of decolourization was measured at different time intervals. All decolourization experiments were carried out in duplicate. Abiotic controls (without microorganisms) were always included.

\section{FT-IR analysis}

PerkinElmer Spectrometer, BX FT-IR (Fourier Transform Infrared Spectroscopy) PerkinElmer, USA), was also used for analyzing biodegradation products. IR spectra were determined using a Mattson 1000 Fourier Transform-infrared (FT-IR) spectrophotometer on a $\mathrm{KBr}$ disc.

\section{Results and discussion}

Immobilized microorganisms provide several advantages over free cells in environmental and agricultural applications or industrial fermentation (Park and Chang 2000). For example, immobilized cultures tend to have a higher level of enzyme activity and are more resistant to environmental conditions such as $\mathrm{pH}$, or exposure to toxic chemical substances than suspension cultures (Couto 2009) and immobilization protects the cells from shear damage (Abraham et al. 1991, Fiedurek and Ilczuk 1991, Vassilev and Vassileva 1992). Another advantage of cell immobilization is a reduction in the protease activity and contamination risk (Couto 2009). So, a variety of matrices have been used for cell immobilization such as natural polymeric gels (agar, carrageenan, alginate, chitosan and cellulose derivatives), synthetic polymers (polyacrylamide, polyurethane, polyvinyl) and solid or porous matrix (Katzbauer et al. 1995). In this study, immobilized bacterial cells (L. fusiformis B26) in agar, Ca-alginate and pumice were used for decolourization of Turquoise Blue HFG.

\section{Optimization of immobilization conditions for agar matrix Effect of agar concentration}

To determine the effect of agar concentration for immobilization of B26 bacterium on bio-decolourization of Turquoise Blue HFG, we tested $3 \%, 4 \%, 5 \%$ and $6 \%$ agar concentrations. The initial cell concentration in agar matrix was $1 \%(0.25 \mathrm{~g})$ and experiments were performed at $40^{\circ} \mathrm{C}$. As shown in Fig. 2 the results are very similar with each other. The decolourization rates of Turquoise Blue HFG by immobilized cells of B26 in $3 \%, 4 \%, 5 \%$ and $6 \%$ agar were $47 \%, 46 \%, 44 \%$, and $45 \%$, respectively. The highest decolourization (47\%) was observed with blocks prepared by using 3\% (w/v) agar. Similarly, maximum yield was obtained for lipase production when cells were immobilized in 3\% agar. This could be attributed to the reduction in the diffusion efficiency of the nutrients and oxygen into the gel matrix, or to limitation of enzyme release out of it due to its high rigidity (Joseph et al. 2006). However, there was no considerable difference when compared to other agar concentrations. So, all the agar concentrations were used for the determination of the effect of cell concentration and temperature.

\section{Effect of cell concentration}

Fig. 3 shows the effect of the initial cell concentration in the agar for the bio-decolourization of Turquoise Blue HFG by immobilized cells. Inoculated flasks with different cell concentrations $(0.25$ and $0.5 \mathrm{~g})$ entrapped in $3 \%, 4 \%, 5 \%$ and

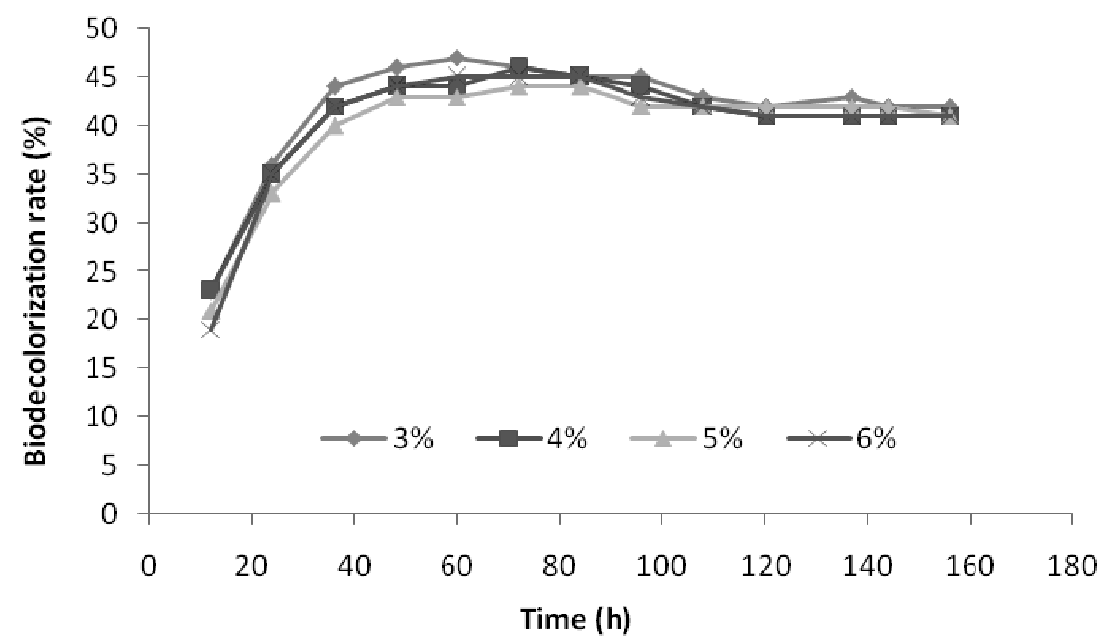

Fig. 2. Effect of agar concentration on decolorization of Turquoise Blue HFG by immobilized cells of $L$. fusiformis B26 (1\% wet cell pellet) at $40^{\circ} \mathrm{C}$ in TSB media 
$6 \%$ agar were incubated at $40^{\circ} \mathrm{C}$ for $24 \mathrm{~h}$. According to our results, the color removal rates were increased for all agar concentrations when the initial cell concentration was increased. The maximum bio-decolourization $(55.55 \%)$ was achieved at $0.5 \mathrm{~g}$ of wet cell weight in the $3 \%$ agar matrix. Similar trend was also reported in enzyme biosynthesis by Bisht et al. (2013). But they determined that very high cell concentrations led to slow activity due to the diffusion limitation of nutrients. In a similar study, it was determined that low levels of entrapped cells led to rapid enzyme biosynthesis, while high levels caused diffusion limitation of nutrients (Jouenne et al. 1993). Also, Cheetham et al. (1985) reported that at very high cell concentrations, the beads were actually less active because the porous structure of the beads was lost. In this study, very high cell concentration was not studied. But it may be tested in further studies in the future.

\section{Effect of temperature}

The bacterium L. fusiformis B26 used in the present study was previously isolated from thermal sources in our laboratory (Dogan et al. 2013). So it was significant to determine the effect of temperature on the bio-decolourization by immobilized cells and the experiments were performed at 40 and $50^{\circ} \mathrm{C}$. Fig. 4 shows that the color removal rate at $40^{\circ} \mathrm{C}$ was higher than that at $50^{\circ} \mathrm{C}$. The maximum rates of decolourization ranged from $37.23 \%$ to $41.72 \%$ at $50^{\circ} \mathrm{C}$ and from $44 \%$ to $47 \%$ at $40^{\circ} \mathrm{C}$ when $0.25 \mathrm{~g}$ cell was entrapped in agar matrixes (3-6\%) and from $36.9 \%$ to $40 \%$ at $50^{\circ} \mathrm{C}$ and from $50.49 \%$ to $55.55 \%$ at $40^{\circ} \mathrm{C}$ when $0.5 \mathrm{~g}$ cell was entrapped in agar matrixes (3-6\%). Therefore, decolourization efficiency at $40^{\circ} \mathrm{C}$ is better than at $50^{\circ} \mathrm{C}$. But, it is necessary to determine the optimum temperature in different bacterial cultures in order to obtain maximum bacterial decolourization. For example, in one study, over the range of 20 to $45^{\circ} \mathrm{C}$, the specific decolourization rate of immobilized cells of Pseudomonas luteola increased as the temperature increased (Chang et al. 2001).

\section{Effect of Ca-alginate beads}

To determine the decolourization efficiency of immobilized cells of B26 in Ca-alginate beads, three different cell concentrations were used and experiments were performed at 40 and $50^{\circ} \mathrm{C}$. The results show that percent decolourization of Turquoise Blue HFG by immobilized cells in Ca-alginate slightly increased with the increase in initial cell concentration (Fig. 5). At the first $48 \mathrm{~h}$ of incubation, dye removal rates of Ca-alginate beads loaded with $0.5,1.0$ and $2.0 \mathrm{~g}$ of wet cell pellet were $63.64 \%, 63.16 \%$ and $69.62 \%$, respectively, at $40{ }^{\circ} \mathrm{C}$. Similarly, also at $50^{\circ} \mathrm{C}$ decolorization rates were $50.41 \%, 51.81 \%$ and $57.69 \%$ when $0.5,1.0$ and $2.0 \mathrm{~g}$ of wet cell pellets were used for immobilization in Ca-alginate after $48 \mathrm{~h}$ of incubation respectively. In addition, $64.1 \%$ dye was decolorized by $2.0 \mathrm{~g}$ cell pellet entrapped in Ca-alginate at the $28^{\text {th }}$ hour at $50^{\circ} \mathrm{C}$. So, the highest dye removal both at 40 and $50^{\circ} \mathrm{C}$ was observed with $2.0 \mathrm{~g}$ of wet cell pellet in Ca-alginate beads. Also, $40^{\circ} \mathrm{C}$ was more suitable for decolourization by immobilized cells of B26 in general. However, in another study, Chang et al. (2001) showed that over the range of 20 to $45^{\circ} \mathrm{C}$, the specific decolourization rate of immobilized cells of Pseudomonas luteola increased as the temperature increased.

\section{Effect of pumice}

Fig. 6 shows the effect of 0.5 and $1.0 \mathrm{~g}$ of pumice particles loaded with B26 cells on bio-decolourization of Turquoise Blue $\mathrm{HFG}$ at 40 and $50^{\circ} \mathrm{C}$. As seen in Fig. 6, in general, bacterial decolourization showed a negligible difference when the inoculum amount was $0.5 \mathrm{~g}$ or $1.0 \mathrm{~g}$ of pumice. At the $28^{\text {th }}$ $\mathrm{h}$ of incubation, $36.14 \%$ and $39.47 \%$ dye was decolorized by $0.5 \mathrm{~g}$ and $1.0 \mathrm{~g}$ of pumice particles loaded with B26 cells respectively at $40^{\circ} \mathrm{C}$. However, at the same temperature the maximum decolourization rates were $50.6 \%$ and $50 \%$ with $0.5 \mathrm{~g}$ and $1.0 \mathrm{~g}$ pumice respectively. Similar results were obtained at $50^{\circ} \mathrm{C}$. The highest decolourization rates were $41.57 \%$ and $40.52 \%$ when using $0.5 \mathrm{~g}$ and $1.0 \mathrm{~g}$ pumice particles respectively. On the other hand, if the temperature was compared, the decolourization efficiency at $40^{\circ} \mathrm{C}$ was better than at $50^{\circ} \mathrm{C}$.

Considering all the results, between the different immobilization matrices (i.e., agar, Ca-alginate and pumice) for removal of Turquoise Blue HFG by L. fusiformis B26 cells, Ca-alginate was the most suitable matrix. In all sets of experiments, $2.0 \mathrm{~g}$ of wet cells of $L$. fusiformis B26 entrapped in alginate showed the highest color removal performance

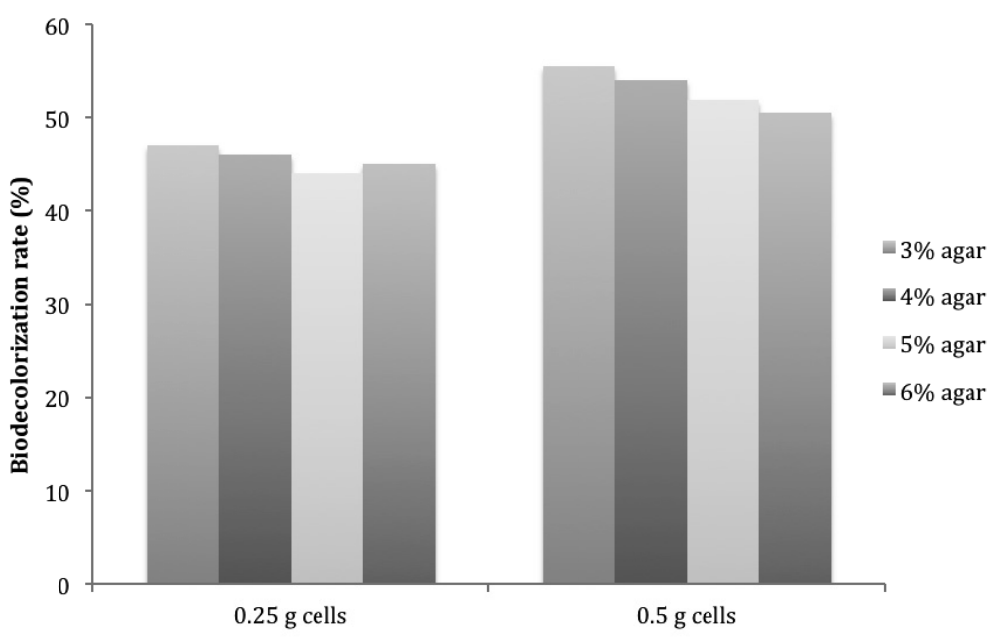

Fig. 3. Effect of entrapped cell concentrations on decolorization of Turquoise Blue HFG with different agar concentrations at $40^{\circ} \mathrm{C}$ in TSB media 

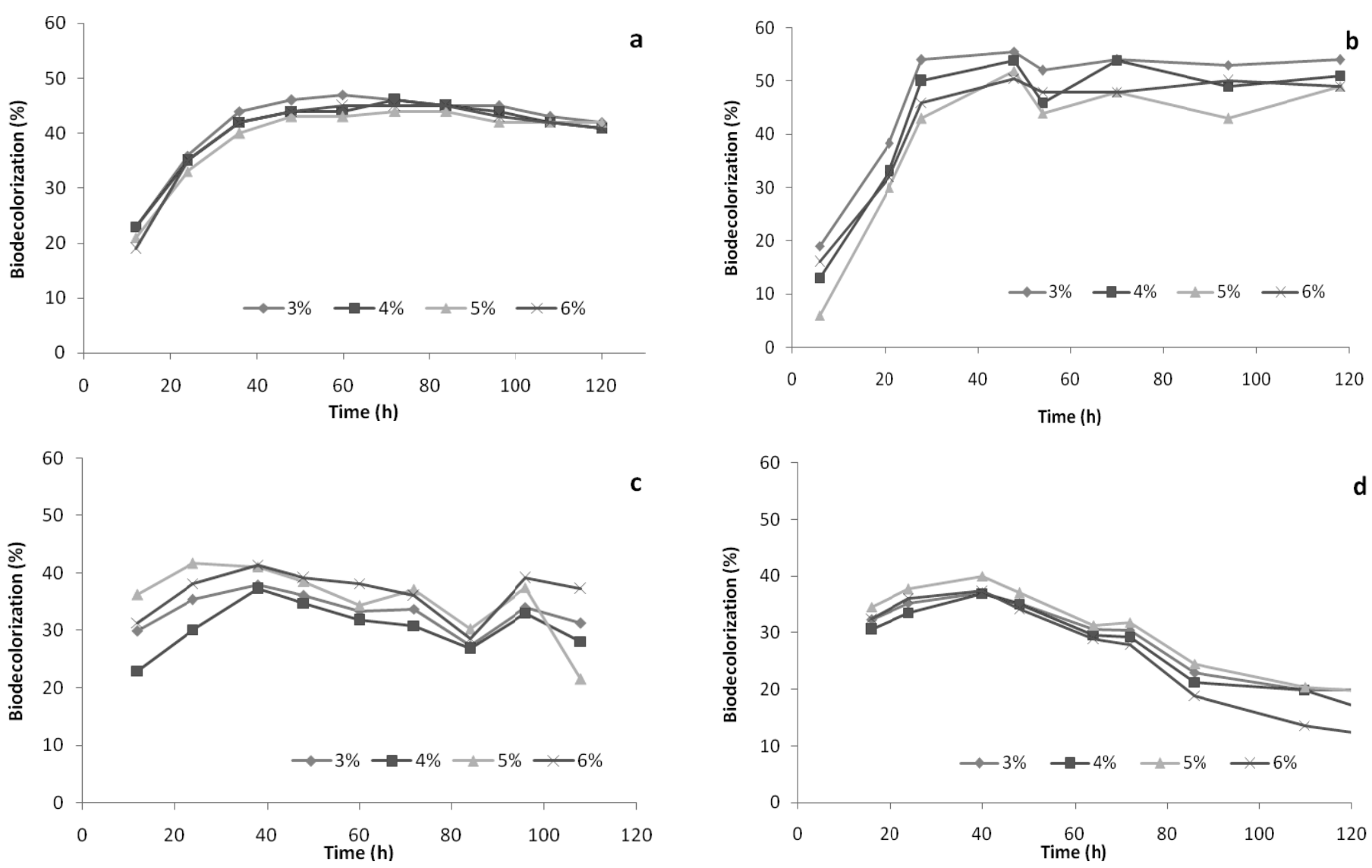

Fig. 4. Effect of different temperature on decolorization of Turquoise Blue HFG by immobilized cells in different agar concentration $(3 \%, 4 \%, 5 \%, 6 \%)$, a: $1 \%$ cell concentration at $40^{\circ} \mathrm{C}$, b: $2 \%$ cell concentration at $40^{\circ} \mathrm{C}$, c: $1 \%$ cell concentration at $50^{\circ} \mathrm{C}$, d: $2 \%$ cell concentration at $50^{\circ} \mathrm{C}$
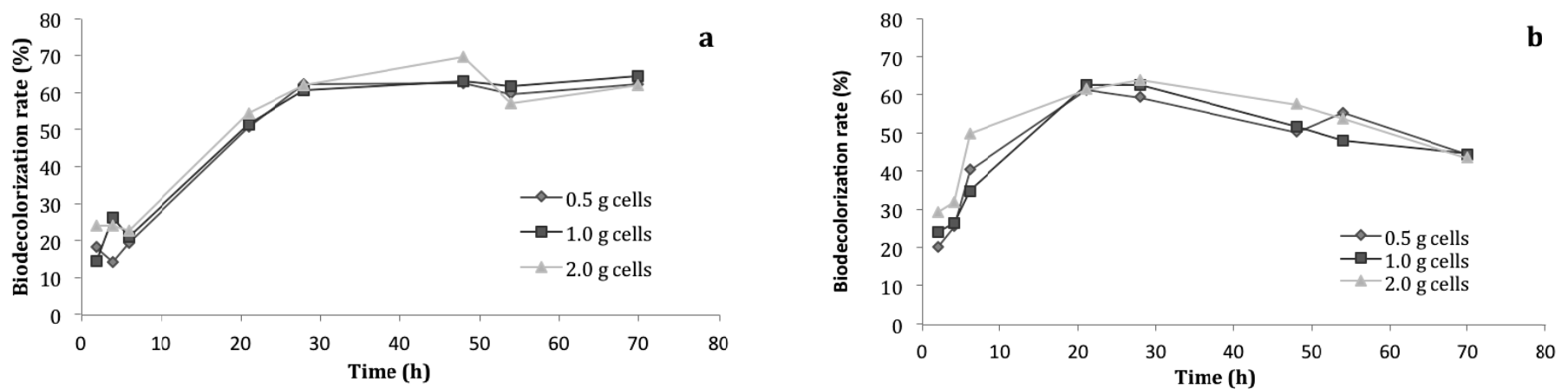

Fig. 5. Decolorization of Turquoise Blue HFG by immobilized cells of $L$. fusiformis B26 in Ca-alginate with different cell concentrations at $40(\mathrm{a})$ and $50^{\circ} \mathrm{C}(\mathrm{b})$ in TSB media
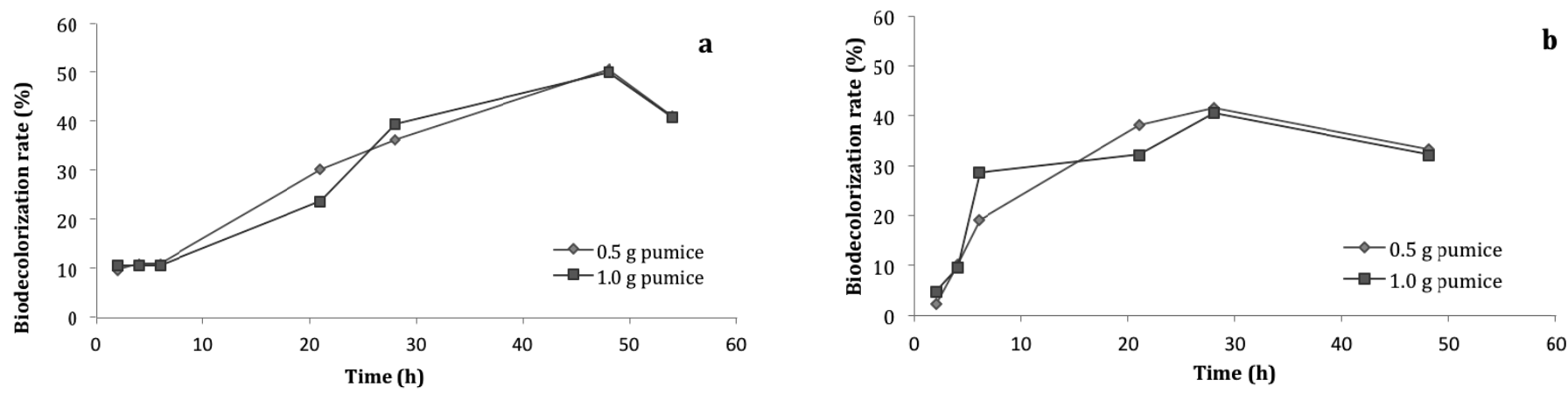

Fig. 6. Decolorization of Turquoise Blue HFG by immobilized cells of $L$. fusiformis B26 in pumice with different inoculum amount at 40 (a) and $50^{\circ} \mathrm{C}(\mathrm{b})$ in TSB media 
at $40^{\circ} \mathrm{C}$. A similar result was obtained for also pullulanase production and enzyme activity of immobilized cells of B. licheniformis NRC22. Six different immobilization matrices were used and the best result was found with Ca-alginate (Abdel-Naby et al. 2011).

On the other hand, the decolourization of Turquoise Blue HFG by free cells of L. fusiformis B26 was reported in our previous paper (Dogan et al. 2013). Free cells of B26 bacterium removed only $36.02 \%$ of same dye at $40^{\circ} \mathrm{C}$ and $53.63 \%$ at $50^{\circ} \mathrm{C}$. So, when these results were compared to this study, it was observed that the activity of the immobilized cells was higher than that of the free cells. This may be due to the fact that immobilized cells are more resistant (Shin et al. 2002).

\section{Analysis of metabolites}

The FTIR spectrum of Turquoise Blue HFG showed presence of different peaks at $3445 \mathrm{~cm}^{-1}$ for $-\mathrm{C}-\mathrm{H}$ stretching of single bridge alcoholic or phenolic compound, $2925 \mathrm{~cm}^{-1}$ for $-\mathrm{CH}_{2}$ stretching of alkanes, $2362 \mathrm{~cm}^{-1}$ for displayed $\mathrm{C}=\mathrm{N}$ stretching, $1559 \mathrm{~cm}^{-1}$ for $-\mathrm{C}-\mathrm{H}$ stretching of aromatic ring, $1193 \mathrm{~cm}^{-1}$ for $-\mathrm{S}=\mathrm{O}$ stretching of sulfites, $1041 \mathrm{~cm}^{-1}$ for $-\mathrm{S} \mathrm{O}$ stretching of sulfonic acids.
After the biodegradation by B26 immobilized in Ca- alginate, a significant reduction in IR peaks was observed in the $2361 \mathrm{~cm}^{-1}$ and $2342 \mathrm{~cm}^{-1}$ region of metabolites, which suggests absence of charged amines in the produced metabolites. In addition, the strong peak at around $3445 \mathrm{~cm}^{-1}$ was assigned to the stretching of N-H (Harshad et al. 2012). Moreover, peak of the $2925 \mathrm{~cm}^{-1}$ in pure dye molecule was not shown in after biodegradation. The absence of peak at $1643 \mathrm{~cm}^{-1}$ was not disappeared for aromatic ring (Fig. 7b).

After the biodegradation by $\mathrm{B} 26$ immobilized onto pumice, metabolite bands at $1643 \mathrm{~cm}^{-1}$ was pointed that towards the formation of aromatic compounds as benzaldehyde and benzoic acid. A new band was observed at $1335 \mathrm{~cm}^{-1}$ represented $\mathrm{C}-\mathrm{H}$ deformation of $\mathrm{CH}_{2}$. Moreover ester $\mathrm{C}=\mathrm{O}$ band at $1724.3 \mathrm{~cm}^{-1}$ peaks was seen in the spectrum. The formation of hydrocarbon aliphatic compounds could be explained by the absorption band at $3075 \mathrm{~cm}^{-1}$ (Fig. 7c) (Swapnil et al. 2011).

FT-IR metabolites after the biodegradation by B26 immobilized in agar; (C-H) bands at $2963,9 \mathrm{~cm}^{-1}$, aromatic $\mathrm{C}-\mathrm{H}$ band at $3073 \mathrm{~cm}^{-1}$, aromatic $\mathrm{C}=\mathrm{C}$ bands at $1600 \mathrm{~cm}^{-1}$, ester $\mathrm{C}=\mathrm{O}$ band at $1725 \mathrm{~cm}^{-1}$ (Fig. 7d). Same results were performed in Ayed et al.'s study (Ayed et al. 2010).

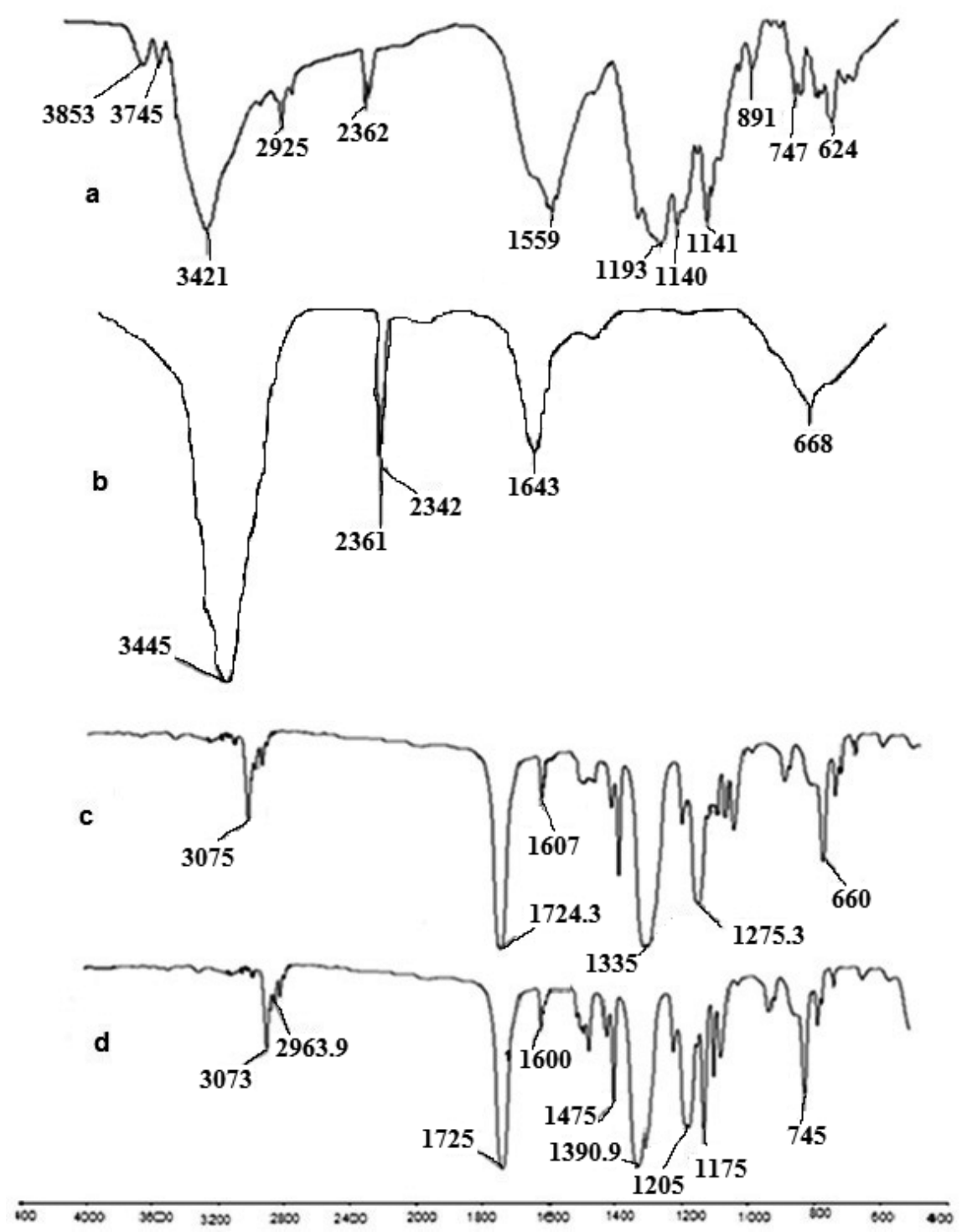

Fig. 7. FT-IR Spectrums; a: pure Turquoise Blue HFG, b; biodegradation by B26 immobilized in Ca- alginate (50 h), c; biodegradation by B26 immobilized in pumice $(50 \mathrm{~h})$, d; biodegradation by B26 immobilized in agar $(50 \mathrm{~h})$ 


\section{Conclusions}

Bacterial decolourization of synthetic dyes under certain environmental conditions has attracted considerable interest because microorganisms can tolerate and remove dyes. Although, there are many papers on bacterial dye decolorization, the use of immobilized thermophilic bacteria for textile dye decolorization has not been deeply investigated yet. In the present study, immobilized cells of $L$. fusiformis B26 isolated from thermal region of Denizli, Turkey were used for color removal. We optimized immobilization conditions such as matrix type, cell density, temperature and matrix concentration for achieving maximum decolorization effect by the selected bacterial isolate. And, based on the above results, it can be concluded that alginate matrix was better than agar and pumice for cell immobilization with the aim of Turquoise Blue HFG decolourization. Also, the decreases of color removal rates were showed the production of intermediate metabolites in biodegradation process of this dye. This conclusion was supported by FTIR. The FTIR results indicate that the Turquoise Blue HFG was transformed by $L$. fusiformis B26. The results obtained from this study will be a useful reference for further development of effective decolourization bioprocesses utilizing immobilized bacterial cells as the biocatalyst.

\section{References}

Abdel-Naby, M.A., Osman, M.Y. \& Abdel-Fattah, A.F. (2011). Production of pullulanase by free and immobilized cells of Bacillus licheniformis NRC22 in batch and continuous cultures, World Journal of Microbiology and Biotechnology, 27, pp. 2903-2911.

Abraham, T.E., Jamuna, R., Bansilal, C.V. \& Ramakrishna, S.V. (1991). Continuous synthesis of glucoamylase by immobilized fungal mycelium of Aspergillus niger, Starch-Starke, 43, pp. 113-116.

Adinarayana, K., Jyothi, B. \& Ellaiah, P. (2005). Production of alkaline protease with immobilized cells of Bacillus subtilis PE-11 in various matrices by entrapment technique, AAPS PharmSciTech, 6, pp. 391-397.

Ayed, L., Khelifi, E., Jannetc, H.B., Miladi, H., Cheref, A., Achour, S. \& Bakhrouf, A. (2010). Response surface methodology for decolorization of azo dye Methyl Orange by bacterial consortium: Produced enzymes and metabolites characterization, Chemical Engineering Journal, 165, pp. 200-208

Banat, I.M, Nigam, P., Singh, D. \& Marchant, R. (1996). Microbial decolourization of textile dyes containing effluents, Bioresource Technology, 58, pp. 217-227.

Behera, S., Kar, S., Mohanty, R.C. \& Ray, R.C. (2010). Comparative study of bio-ethanol production from mahula (Madhuca latifolia L.) flowers by Saccharomyces cerevisiae cells immobilized in agar agar and Ca-alginate matrices, Applied Energy, 87, pp. 96-100.

Bisht, D., Yadav, S.K. \& Darmwal, N.S. (2013). Optimization of immobilization conditions by conventional and statistical strategies for alkaline lipase production by Pseudomonas aeruginosa mutant cells: scale-up at bench-scale bioreactor level, Turkish Journal of Biology, 37, pp. 392-404.

Chacko, J.T. \& Subramaniam, K. (2011). Enzymatic degradation of azo dyes-a review, International Journal of Environmental Science, 1, pp. 1250-1260.

Chandel, A.K., Chan, E.S., Rudravaram, R., Narasu, M.L., Rao, L.V. \& Pogaku, R. (2007). Economics and environmental impact of bio-ethanol production technologies: an appraisal, Biotechnology and Molecular Biology Reviews, 2, pp. 14-32.
Chang, J.-S., Chou, C. \& Chen, S.Y. (2001). Decolorization of azo dyes with immobilized Pseudomonas luteola, Process Biochemistry, 36, pp. 757-763.

Cheetham, P.S.J., Garrett, C. \& Clark, L. (1985). Isomaltulose production using immobilized cells, Biotechnology and Bioengineering, 27, pp. 471-481.

Couto, S.R. (2009). Dye removal by immobilized fungi, Biotechnology Advances, 27, pp. 227-235.

Dogan, N.M., Bozbeyoglu, N., Arar, D., Akdogan, A.H., Topuz, M.C. \& Beyatli, Y. (2013). Investigation of reactive dye Turquoise blue HFG removal with Lysinibacillus fusiformis B26 and detection of metabolites, Fresenius Environmental Bulletin, 22, 9.

Fiedurek, J. \& Ilczuk, Z. (1991). Glucose oxidase biosynthesis using immobilized mycelium of Aspergillus niger, World Journal of Microbiology and Biotechnology, 7, pp. 379-84.

Harshad, S.L., Tatoba, R.W., Avinash, A.K. \& Sanjay, P.G. (2012). Enhanced biodegradation and detoxification of disperse azo dye Rubine GFL and textile industry effluent by defined fungal-bacterial consortium, International Biodeterioration \& Biodegradation, 72, pp. 94-107.

Joseph, B., Ramteke, P.W. \& Kumar, P.A. (2006). Studies on the enhanced production of extracellular lipase by Staphylococcus epidermidis, Journal of General and Applied Microbiology, 52, pp. 315-320.

Jouenne, T., Bonato, H., Mignot, L. \& Junter, G.A. (1993). Cell immobilization in agar layer microporous membrane structures: growth kinetics of gel-entrapment culture and cell leakage limitation by microporous membrane, Applied Microbiology and Biotechnology, 38, pp. 478-481.

Kar, S. \& Ray, R.C. (2008). Statistical optimization of a-amylase production by Streptomyces erumpens MTCC 7317 cells in calcium alginate beads using response surface methodology, Polish Journal of Microbiolgy, 57, pp. 49-57.

Kar, S., Swain, M.R. \& Ray, R.C. (2009). Statistical optimization of alpha-amylase production with immobilized cells of Streptomyces erumpens MTCC 7317 in Luffa cylindrical L. sponge discs, Applied Biochemistry and Biotechnology, 152, pp. 177-188.

Kariminiaae-Hamedaani, H.R., Sakurai, A. \& Sakakibara, M. (2007). Decolorization of synthetic dyes by a new manganese peroxidase producing white rot fungus, Dyes and Pigments, 72, pp. 157-162.

Katzbauer, B., Narodoslawsky, B. \& Moser, A. (1995). Classification system for immobilization techniques, Bioprocess Engineering, 12, pp. 173-179.

Khalid, A., Kausar, F., Arshad, M., Mahmood, T. \& Ahmed, I. (2012). Accelerated decolorization of reactive azo dyes under saline conditions by bacteria isolated from Arabian seawater sediment, Applied Microbiology and Biotechnology, 96, pp.1599-1606.

Mohana, S., Shrivastava, S., Divecha, J. \& Madamwar, D. (2008). Response surface methodology for optimization of medium for decolorization of textile dye Direct Black 22 by a novel bacterial consortium, Bioresource Technology, 99, pp. 562-569.

Nigam, J.N. (2000). Continuous ethanol production from pineapple cannery waste using immobilized yeast cells, Journal of Biotechnology, 80, pp. 189-193.

Novotny, C., Dias, N., Kapanen, A., Malachova, K., Vandrovcova, M., Itavaara, M. \& Lima, N. (2006). Comparative use of bacterial, algal and protozoan tests to study toxicity of azo- and anthraquinone dyes, Chemosphere, 63, pp. 1436-1442.

Park, J.K. \& Chang, H.N. (2000). Microencapsulation of microbial cells, Biotechnology Advances, 18, pp. 303-319.

Puvaneswari, N., Muthukrishnan, J. \& Gunasekaran, P. (2002). Biodegradation of benzidine based azodyes Direct red and Direct blue by the immobilized cells of Pseudomonas fluorescens D41, Indian Journal of Experimental Biology, 40(10), pp. 1131-1136.

Shin, M., Nguyen, T. \& Ramsay, J. (2002). Evaluation of support materials for the surface immobilization and decoloration of 
amaranth by Trametes versicolor, Applied Microbiology and Biotechnology, 60, pp. 218-223.

Swapnil, S.P., Dayanand, C.K., Asmita, V.O. \& Jyoti, P.J. (2011). Textile dye degradation by bacterial consortium and subsequent toxicological analysis of dye and dye metabolites using cytotoxicity, genotoxicity and oxidative stress studies, Journal of Hazardous Materials, 186, pp. 713-723.

Vandevivere, P.C., Bianchi, R. \& Verstraete, W. (1998). Treatment and reuse of wastewater from the textile wet-processing industry: review of emerging technologies, Journal of Chemical Technology and Biotechnology, 72, pp. 289-302.
Vassilev, N. \& Vassileva, M. (1992). Production of organic acids by immobilized filamentous fungi, Mycological Research, 96, pp. 563-570.

Yang, Q., Yang, M., Pritsch, K., Yediler, A., Hagn, A., Schloter, M. \& Kettup, A. (2003). Decolorization of synthetic dyes and production of manganese-dependent peroxidase by new fungal isolates, Biotechnology Letters, 25, pp. 709-713.

Zou, H., Ma, W. \& Wang, Y. (2015). A novel process of dye wastewater treatment by linking advanced chemical oxidation with biological oxidation, Archives of Environmental Protection, 41, 4, pp. 33-39. 